\section{Anticipatory syringe drivers: a step too far}

\author{
Ben Bowers, ${ }^{1}$ Richella Ryan, ${ }^{1}$ Sarah Hoare, ${ }^{1}$ Kristian Pollock, ${ }^{2}$ \\ Stephen Barclay ${ }^{\odot}$
}

The recent Gosport War Memorial Hospital inquiry ${ }^{1}$ has increased UK patient, public and clinician awareness about syringe drivers for continuous subcutaneous delivery of opioids and other medications at the end of life. ${ }^{23}$ The inquiry found that at least 456 patients died where opioids had been prescribed and administered in unjustified doses, commonly via syringe drivers. In safe hands, syringe drivers facilitate appropriate and effective control of pain and other symptoms for patients who are no longer able to swallow or absorb oral medication, commonly when close to the end of life. The Gosport findings highlight the importance of 'safe hands'. In an overstretched clinical climate in which clinicians are encouraged to plan ahead to optimise patient care, Gosport is a timely warning of the potential dangers of 'anticipatory syringe drivers' prescribed in anticipation of future symptoms at the end of life.

The anticipatory prescribing and administration of opioids in Gosport hospital was highly anomalous and did not reflect standard palliative care practice. A serious category error was common; most people were in hospital for rehabilitation and were not terminally ill. The inquiry underlined that opioid delivery to the wrong people, at the wrong time, in the wrong doses, hastened many deaths. These

\footnotetext{
'Department of Public Health and Primary Care, University of Cambridge, Cambridge, United Kingdom

${ }^{2}$ School of Health Sciences, University of Nottingham, Nottingham, United Kingdom

Correspondence to Mr Ben Bowers, Department of Public Health and Primary Care, University of Cambridge, Cambridge CB1 8RN, UK; bb527@medschl.cam.ac.uk
}

unacceptable practices highlight the risks of prescribing anticipatory syringe drivers (along with excessive starting doses or wide dose ranges) to be started by third parties whose clinical assessment skills are unknown to the prescriber. This can result in syringe drivers being started, or doses increased, without skilled assessment and consideration of potentially reversible causes of symptoms and clinical deterioration.

Anticipatory prescribing of injectable drugs ahead of need is regarded as best practice for the dying in the $\mathrm{UK}^{4}{ }^{4}$ ensuring that relevant drugs are available in the home 'Just in Case' they are needed for 'as required' or pro re nata (prn) injections in the future. There is a danger that this may be conflated with anticipatory syringe driver prescribing. The two should be regarded as distinct interventions. Commencing a syringe driver marks a more significant change in patient care. Syringe drivers should only be prescribed after symptoms have developed, drugs and doses being decided in the light of response to previous injection doses. Once started, it is rare to discontinue a syringe driver, and family members often perceive death occurs soon afterwards. ${ }^{67}$ Before starting a syringe driver, it is vital to explore patient and family understanding and wishes, to discuss the goals of treatment, including the possible effects of administered drugs and to advise that drugs given in doses appropriate for symptom control will not hasten death. ${ }^{8} 9$ These conversations require the skills of a compassionate, knowledgeable and experienced doctor or nurse.
The authors are aware that on occasions nurses may ask doctors to prescribe an anticipatory syringe driver when it is evident that a patient's condition may deteriorate soon. This can avoid delays in getting drugs prescribed 'out of hours' by practitioners unfamiliar with the clinical situation. ${ }^{10}{ }^{11}$ Recent local fieldwork by our team found that 2 of 13 general practitioners (GP) interviewed were comfortable with prescribing anticipatory syringe drivers at the end of life. They trusted community nursing colleagues to give these drugs appropriately. Conversely, other GPs thought that syringe drivers should only be prescribed in response to symptoms developing and after a doctor had made a faceto-face assessment to rule out any reversible symptoms.

Guidance from the National Institute for Health and Care Excellence (NICE) ${ }^{4}$ Healthcare Improvement Scotland ${ }^{5}$ and the British Medical Association ${ }^{12}$ lacks clarity about anticipatory syringe drivers. NICE guidance simply advises ensuring suitable anticipatory medicines and routes are prescribed as early as possible.

\section{RECOMMENDATIONS}

In the absence of appropriate guidelines, we recommend syringe drivers should only be prescribed after an experienced doctor or nurse prescriber has reviewed the patient in person in order to consider the causes of deterioration and associated symptoms, evaluate reversibility, establish a dying diagnosis and appraise the effectiveness of previously administered prn drug injections. There is also an urgent need for research to guide safe and effective practice in this area.

Contributors $\mathrm{BB}, \mathrm{RR}, \mathrm{SH}, \mathrm{KP}$ and $\mathrm{SB}$ contributed to the conception, drafting and revision of this piece.

Funding The authors have not declared a specific grant for this research from any funding agency in the public, commercial or not-for-profit sectors.

Disclaimer The views expressed are those of the authors and not necessarily 
those of the NHS, the NIHR or the Department of Health and Social Care.

Competing interests $\mathrm{BB}, \mathrm{RR}, \mathrm{KP}$ and $\mathrm{SB}$ are undertaking research into anticipatory prescribing care in the community. BB and SB were funded by the National Institute for Health Research (NIHR) Collaboration for Leadership in Applied Health Research and Care (CLAHRC) East of England to undertake the General Practitioner interview study. BB is funded by the NIHR School for Primary Care Research. $R R$ is funded by the Eastern Deanery of the National Health Service.

Patient consent for publication Not required.

Provenance and peer review Not commissioned; internally peer reviewed.

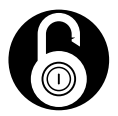

\section{OPEN ACCESS}

Open access This is an open access article distributed in accordance with the Creative Commons Attribution Non Commercial (CC BY-NC 4.0) license, which permits others to distribute, remix, adapt, build upon this work noncommercially, and license their derivative works on different terms, provided the original work is properly cited, appropriate credit is given, any changes made indicated, and the use is noncommercial. See: http://creativecommons. org/licenses/by-nc/4.0/.

(C) Author(s) (or their employer(s)) 2019. Re-use permitted under CC BY-NC. No commercial re-use. See rights and permissions. Published by BMJ.
Check for updates

To cite Bowers B, Ryan R, Hoare S, et al. BMJ Supportive \& Palliative Care 2019;9:149-150.

Received 25 November 2018

Accepted 27 February 2019

\section{REFERENCES}

1 Panel GI. Gosport War Memorial Hospital: the report of the Gosport independent panel, 2018. Available: https://www.gosportpanel.independent. gov.uk/media/documents/070618 CCS207_CCS03183220761_Gosport_ Inquiry_Whole_Document.pdf [Accessed 21 Nov 2018].

2 Darbyshire P, Ion R. The Gosport War Memorial Hospital Panel report and its implications for nursing. J Adv Nurs 2019;75:258-63.

3 Knights D, Knights F, Barclay S. 'Please make comfortable': prescribing opioids in the wake of Gosport. Br J Gen Pract 2018;68:462-3.

4 National Institute For Health and Care Excellence. Care of dying adults in the last days of life: NG31, 2015. Available: www.nice.org.uk/guidance/ng31 [Accessed 20 Nov 2018].

5 Scotland HI. Scottish palliative care guidelines: anticipatory prescribing, 2016. Available: www.palliativecaregu idelines.scot.nhs.uk/guidelines/pain/ Anticipatory-Prescribing.aspx [Accessed 20 Nov 2018].

6 Payne S, Turner M, Seamark D, et al. Managing end of life medications at home-accounts of bereaved family carers: a qualitative interview study. BMJ Support Palliat Care 2015;5:181-8.
7 Sheehy-Skeffington B, McLean $\mathrm{S}$, Bramwell $\mathrm{M}$, et al. Caregivers experiences of managing medications for palliative care patients at the end of life: a qualitative study. Am J Hosp Palliat Care 2014;31:148-54.

8 Association for Palliative Medicine. Association for Palliative Medicine position on the double effect, 2009. Available: https://apmonline.org/wpcontent/uploads/2018/03/Double Effect_0902.pdf [Accessed $20 \mathrm{Nov}$ 2018].

9 Neuberger J, Guthrie C, Aarnovitch D, et al. More care, less pathway : a review of the Liverpool Care Pathway, 2013. Available: assets.publishing.service. gov.uk/government/uploads/system/ uploads/attachment_data/file/212450/ Liverpool_Care_Pathway.pdf [Accessed 20 Nov 2018].

10 Bowers B, Ryan R, Kuhn I, et al. Anticipatory prescribing of injectable medications for adults at the end of life in the community: a systematic literature review and narrative synthesis. Palliat Med 2019;33:160-77.

11 Faull C, Windridge K, Ockleford $\mathrm{E}$, et al. Anticipatory prescribing in terminal care at home: what challenges do community health professionals encounter? BMJ Support Palliat Care 2013;3:91-7.

12 British Medical Association. Focus on anticipatory prescribing for end of life care, 2018. Available: www.bma.org. uk/advice/employment/gp-practices/ service-provision/prescribing/focus-onanticipatory-prescribing-for-end-of-lifecare [Accessed 20 Nov 2018]. 